\title{
Comparison of social results produced by Russian and foreign companies: case Russian electronic industry
}

\author{
Vladislav Spitsin \\ Department of Management \\ Tomsk Polytechnic University \\ Tomsk, Russia \\ Spitsin_vv@mail.ru \\ Aleksandr Mikhalchuk \\ Department of Higher Mathematics \\ Tomsk Polytechnic University \\ Tomsk, Russia \\ Lubov Spitsina \\ Tomsk Polytechnic University \\ Tomsk, Russia
}

\author{
Nataliya Tyuleneva \\ Department of Finance and Accounting \\ Tomsk State University \\ Tomsk, Russia \\ aola79@yandex.ru
}

\author{
Darya Novoseltseva \\ Tomsk Polytechnic University \\ Tomsk, Russia
}

Evgeniya Dyrina

Tomsk Polytechnic University

Tomsk, Russia

zhenya_9309_93@mail.ru

\begin{abstract}
The purpose of this paper is a comparative analysis of the social results of foreign and joint (FJO) and domestic (Russian - RO) enterprises. We analyze the differences between FJO and RO enterprises for the subsection DL "Manufacture of electrical and optical equipment" at the Russian regional level using methods of multivariate statistical analysis. We find the strong positive correlation between the indicators, related the number of employees and payroll fund and positive correlation between the production value, the number of employees and the annual payroll fund. We determined statistically significant differences between FJO enterprises and the RO enterprises by some of the analyzed indicators. Using cluster analysis we confirmed that FJO enterprises are characterized by a smaller size and lower employment compared with RO enterprises. We found only two regions with the high growth rates of employment and payroll, but with low current levels of employment and payroll. The regions, which are major manufacturing centers, do not demonstrate high growth rates of employment and payroll.
\end{abstract}

Keywords - foreign and joint enterprises; domestic enterprises; social results; multivariate statistical analysis; manufacture of electrical and optical equipment; Russian regions

\section{INTRODUCTION}

Since 2006, foreign and joint enterprises (foreign and joint ownership - FJO) have been intensively created in several industries of the Russian economy. High growth rates of the shipped products of FJO enterprises were noted in subsection DL "Manufacture of electrical and optical equipment" (subsection DL according to the NACE Rev. 1.1. or C26+C27 according to the NACE Rev. 2, Eurostat classification of

The research is made with financial support from Russian Foundation for Basic Research (RFBR). Research project is "Comprehensive economic and statistical impact analysis of joint and foreign ownership enterprises on the industry development in Russia and its regions”, №15-06-05418 a. economic activities). Share of FJO enterprises reached $18 \%$ of total production of subsection DL in 2013.

The purpose of this paper is a comparative analysis of the social results of the subsection DL "Manufacture of electrical and optical equipment" enterprises by types of ownership at the regional level. The research period is 2010-2013. The information base includes statistical data at the level of Russia and its regions [1]. We applied the following methods of analysis: correlation, factor, cluster and dispersion analysis and used software product "Statistics" for calculations [2, 3].

Modern economists analyze the differences in foreign, joint and national firms' performance [4-10]. The most attention is paid to the role of foreign ownership in labor market conditions and skills, salary and productivity dynamics, innovations and investment activities in manufacturing sectors. Last years the developed countries' influence for developing countries technologies level and manufacturing growth were also researched [6, 8, 9]. The scientists successfully use economic and mathematic models in their analyses. Most investigations examine the firm data or national economy data. They try to form some guidance for national governments based on their conclusions [8]. We examined the differences between RO and FJO enterprises for the subsection DM "Production of Vehicles and Equipment" in the paper [10]. We found that FJO enterprises have on the average higher salaries with lower labor intensity and payroll-output ratio than the same indicators for $\mathrm{RO}$ enterprises.

In this paper we research the subsection DL "Manufacture of electrical and optical equipment", where the process of creating FJO enterprises were slightly less intense than in 
subsection DM. We test the differences between samples of regions and carry out clustering of regions to find the differences between separate regions.

\section{RESEARCH METHODOLOGY}

The 9 indicators (Table 1) were used for the analysis.

TABLE I. IINDICATORS AND THEIR CALCULATIONS

\begin{tabular}{|l|l|}
\hline № & \multicolumn{1}{|c|}{ Indicators $^{\text {a }}$} \\
\hline 1 & Production value \\
\hline 2 & Average monthly salary \\
\hline 3 & Number of employees \\
\hline 4 & Annual payroll fund \\
\hline 5 & Labor intensity (Number of employees / Production value) \\
\hline 6 & Payroll-output ratio (Annual Payroll fund / Production value) \\
\hline 7 & Growth rate of the average monthly salary \\
\hline 8 & Growth rate of number of employees \\
\hline 9 & Growth rate of annual payroll fund \\
\hline
\end{tabular}

a. $a$. The average values for the period of 2010-2013 year

We apply the methods of multivariate statistical analysis (correlation, cluster, factor and variance analysis). Statistical analysis is carried out at the level of Russian regions. We formed two samples of regions for subsection DL:

- The sample of regions in which foreign and joint enterprises produced significant volumes of products.

- The sample of regions in which domestic (Russian) enterprises produced significant volumes of products.

We excluded from the samples the next regions:

- The regions, in which average annual production of subsection DL by the analyzed ownership form was less than 1 billion rubles.

- The regions, in which there were insufficient data for analysis or very anomalous values of relative indicators.

The following samples of regions with different ownership forms of enterprises were received:

- Russian enterprises (RO) - 56 regions;

- $\quad$ Foreign and joint enterprises (FJO) - 21 regions.

Each sample of regions covered more than $70 \%$ of the total employment and payroll fund of subsection DL by the same ownership form. To reduce the variability of the indicators in the statistical analysis, we calculated and used their average values for the period 2010-2013.

\section{RESUlTS OF STATISTICAL ANALYSIS}

\section{A. Correlation and cluster analysis of the indicators.}

To conduct correlation analysis of 9 indicators, the dendrogram based on tree clustering is built.. According to this dendrogram different groups of correlated indicators are allocated depending on linkage distance d (Figure 1). By the reason of significant correlations between indicators' pairs, identified in the correlations analysis, we used the correlation distance as a distance measure between indicators. Ward's method was used to identify rules of the clusters' union. This method is different from all other methods by using dispersion analysis to evaluate the distances between clusters.

Correlation analysis revealed a strong positive linear relationship with the high (close to 1) values of the Pearson correlation coefficient ( $r$, parametric) and Spearman coefficient ( $R$, rank) between groups of indicators at the level of DL:

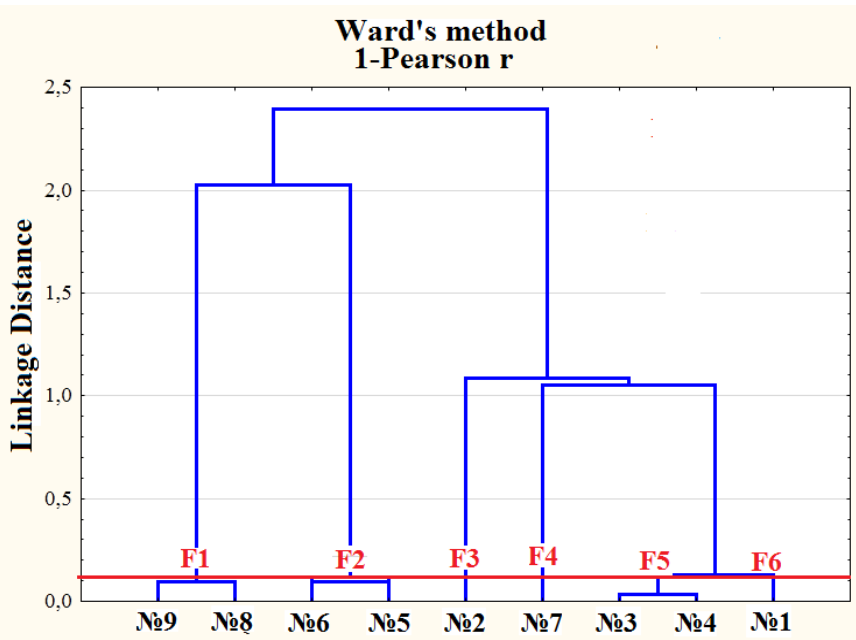

Fig. 1. Vertical dendrogram of the correlation matrix of indicators

- Number of employees and Annual payroll fund( $r=0,96$ and $\mathrm{R}=0,96$ );

- Labor intensity and Payroll-output ratio ( $\mathrm{r}=0,88$ and $\mathrm{R}=0,87$ )

- Growth rate of number of employees and Growth rate of annual payroll fund ( $r=0,91$ and $R=0,83$ ).

There is also a correlation between the production value and the number of employees and the annual payroll fund, but it is weaker $(r=0,85$ and $R=0,78)$.

\section{B. Factor analysis of the indicators}

Strong correlation between some initial indicators allows the use the factor analysis. Factor analysis has two main objectives: to reduce the number of indicators and to define linkage structure between indicators, ie classification parameters. Factor analysis as a method of classification is based on the correlations estimates (factor loadings) between initial indicators and factors (or "new" indicators) within the selected factor model and allows finding the factors significance. The aim of factor analysis is to explain the most dispersion by a relatively small number of factors

Using the factor analysis, the 6-factor model of indicators was formed (Table. 2). The significant (basic) rotated factor loadings (partial correlation coefficients) of the initial indicators on the factors are highlighted in bold color in the table 2 . 
TABLE II. MATRIX 6-FACTOR STRUCTURE OF INDICATORS

\begin{tabular}{|l|l|l|l|l|l|l|}
\hline & \multicolumn{1}{|c|}{ f5 } & \multicolumn{1}{|c|}{ f2 } & \multicolumn{1}{|c|}{ f1 } & \multicolumn{1}{|c|}{ f4 } & \multicolumn{1}{c|}{ f3 } & \multicolumn{1}{c|}{ f6 } \\
\hline №1 & $\mathbf{0 . 9 2 8}$ & -0.202 & 0.007 & 0.075 & 0.176 & $\mathbf{0 . 2 3 8}$ \\
\hline №2 & 0.167 & -0.193 & -0.073 & -0.055 & $\mathbf{0 . 9 6 1}$ & 0.006 \\
\hline №3 & $\mathbf{0 . 9 7 3}$ & 0.055 & 0.007 & 0.134 & -0.031 & -0.147 \\
\hline №4 & $\mathbf{0 . 9 8 2}$ & 0.002 & 0.003 & 0.085 & 0.140 & -0.040 \\
\hline №5 & -0.118 & $\mathbf{0 . 9 2 5}$ & -0.033 & 0.078 & -0.308 & 0.103 \\
\hline №6 & 0.018 & $\mathbf{0 . 9 8 6}$ & -0.044 & 0.016 & 0.007 & -0.098 \\
\hline №7 & 0.190 & 0.067 & 0.069 & $\mathbf{0 . 9 7 4}$ & -0.054 & 0.001 \\
\hline №8 & -0.001 & -0.040 & $\mathbf{0 . 9 8 3}$ & -0.103 & -0.019 & -0.010 \\
\hline №9 & 0.014 & -0.033 & $\mathbf{0 . 9 6 4}$ & 0.207 & -0.066 & 0.012 \\
\hline$\Delta$ & 0.317 & -0.213 & 0.212 & 0.116 & -0.120 & 0.011 \\
\hline
\end{tabular}

These significant factor loadings make it possible to aggregate the initial indicators to interpret relevant factors. The lower line shows the explained dispersion proportion $(\Delta)$ of each factor (or weighting factors). Cumulative dispersion for 6 factors is approximately $98 \%$.

On the basis of the generated six factorial indicators we compared their mean values for the samples of regions with RO and FJO enterprises of subsection DL (Fig. 2).

For the reasons of economic interpretation, backgroundfree factorial indicators are formed and investigated. Factor F6 corresponds to the indicator №1, F3 - №2, F4-№7. Factors F1, F2, F5 are defined as the weighted average of relevant substantive indicators.

In the present case parametric F-test shows that the differences between the RO and FJO enterprises highly significant (at the level of $0,0005>$ p) by a combination of factors due to the highly significant difference between the RO and FJO enterprises for F2 and strongly significant $(0,005>$ $p>0,0005)$ - for F5, F3 and insignificant (at p> 0,10) - for other factors F1, F4,F6. The smallness of the sample of regions with FJO enterprises requires control the results by rank Kruskal-Wallis test, which softens the differences between the RO and FJO enterprises for F3,F5 to a statistically significant.

We find the following statistically significant differences:

- labor intensity and payroll-output ratio (F2) of FJO enterprises is significantly lower than the RO enterprises;

- number of employees and annual payroll fund (F5) of FJO enterprises is lower than the RO enterprises;

- average salary (F3) of FJO enterprises is higher than the Russian (domestic) ones.

\section{Cluster analysis of regions.}

Clustering of Russian regions separately for RO and FJO enterprises was carried out in accordance with Figure 1 and Table 2, in the background-free factor space (F1-F6).

We made two clustering by factors:

1) F5 and F6 (Figure.3);

2) F5 and F1 (Figure.4).

Table 3 shows distribution of Russian regions by clusters.
In these Figures the number of regions in each cluster was indicated in parentheses (blue - RO and red - FJO). F-test shows that the differences between the average values of cluster in their entirety are highly significant for each factor for each type of ownership. The smallness of the clusters samples assumes control of the results rank Kruskal-Wallis test, which confirms the findings of F-test in a bit milder form.

We find that only a few regions show high volume of production and high employment (clusters RO1, RO2, FJO1, FJO2). The leaders are regions with RO enterprises (RO1 Moscow, St. Petersburg). Regions with FJO enterprises lag behind.

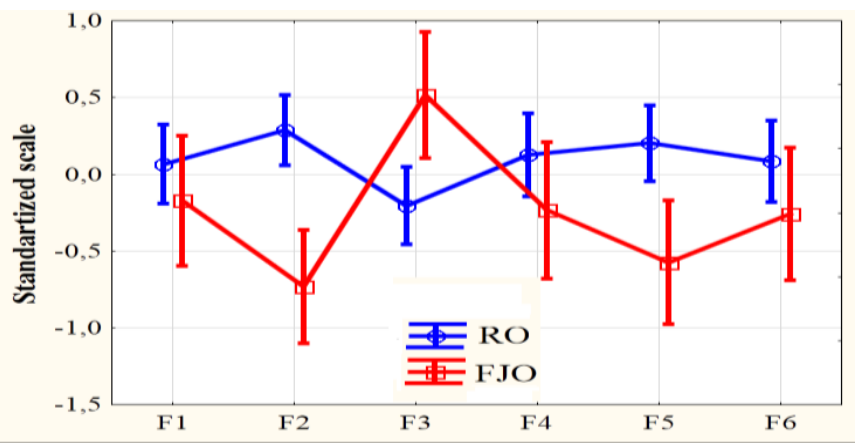

Fig. 2. Standardized mean values of RO and FJO enterprises with $95 \%$ confidence intervals

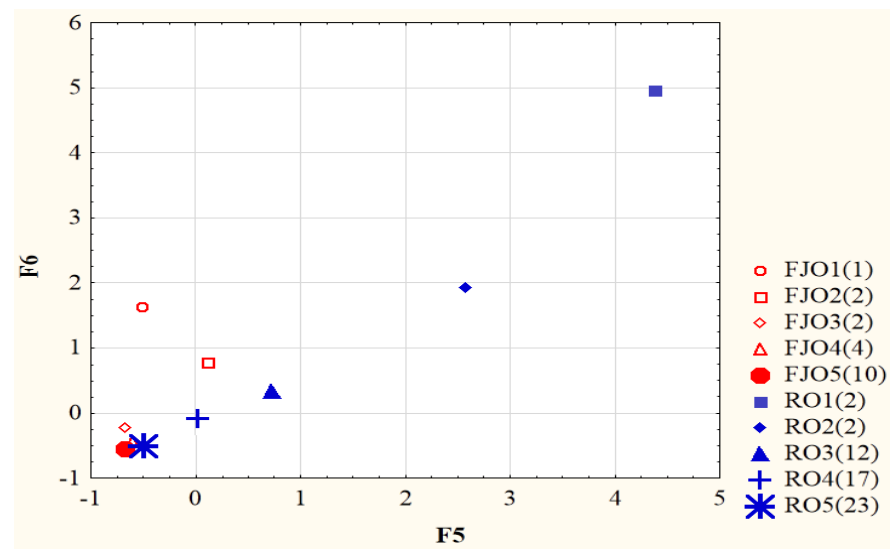

Fig. 3. Scattering of regions clusters with RO and FJO enterprises by the factors F6 and F5

Regions with FJO enterprises are located to the right, i.e., they are characterized by lower employment and payroll fund (F5).

We confirm the conclusion that regions with FJO enterprises are characterized by lower employment and payroll fund (F5). We also find that regions with large enterprises (F5) do not show high growth rates of employment and payroll (F1). Only two clusters (RO6 and FJO5) with two regions demonstrate high growth rates of employment and payroll. 


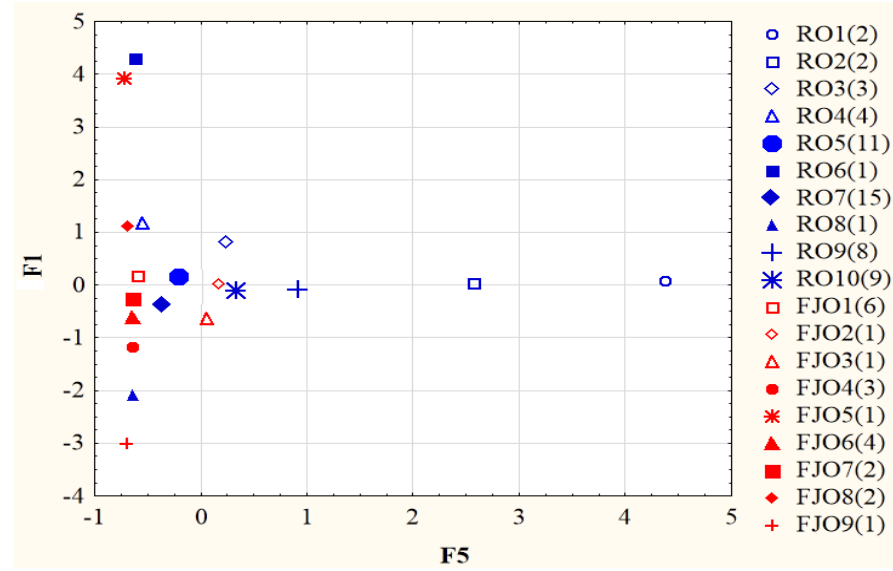

Fig. 4. Scattering of regions clusters with RO and FJO enterprises by the factors F1 and F5

TABLE III. DISTRIBUTION OF RUSSIAN REGIONS By CLUSTERS

\begin{tabular}{|c|c|c|c|c|c|}
\hline Region & $\begin{array}{l}\text { F5- } \\
\text { F1 }\end{array}$ & $\begin{array}{l}\text { F5- } \\
\text { F6 }\end{array}$ & Region & $\begin{array}{l}\text { F5- } \\
\text { F1 }\end{array}$ & $\begin{array}{l}\text { F5- } \\
\text { F6 }\end{array}$ \\
\hline Moscow & RO1 & RO1 & $\begin{array}{l}\text { Kemerovo } \\
\text { region }\end{array}$ & RO7 & RO5 \\
\hline St. Petersburg & RO1 & RO1 & Kirov region & RO5 & RO5 \\
\hline Moscow region & $\mathrm{RO} 2$ & $\mathrm{RO} 2$ & Bryansk region & RO7 & RO5 \\
\hline $\begin{array}{l}\text { Sverdlovsk } \\
\text { region }\end{array}$ & $\mathrm{RO} 2$ & $\mathrm{RO} 2$ & Belgorod region & RO7 & RO5 \\
\hline Samara Region & RO3 & RO3 & Novgorod region & RO5 & RO5 \\
\hline $\begin{array}{l}\text { Nizhny } \\
\text { Novgorod Region }\end{array}$ & RO9 & RO3 & Altai region & RO4 & RO5 \\
\hline Vladimir region & RO9 & RO3 & Irkutsk region & RO4 & RO5 \\
\hline $\begin{array}{l}\text { Republic } \\
\text { Tatarstan }\end{array}$ & RO9 & RO3 & $\begin{array}{l}\text { Volgograd } \\
\text { region }\end{array}$ & RO7 & RO5 \\
\hline Perm Region & RO3 & RO3 & Lipetsk region & RO7 & RO5 \\
\hline $\begin{array}{l}\text { Novosibirsk } \\
\text { region }\end{array}$ & RO9 & $\mathrm{RO} 3$ & Orenburg region & RO4 & RO5 \\
\hline Chuvash region & RO10 & RO3 & Kostroma region & RO6 & RO5 \\
\hline $\begin{array}{l}\text { Kaliningrad } \\
\text { region }\end{array}$ & RO7 & RO4 & Ivanovo region & $\mathrm{RO} 7$ & RO5 \\
\hline Ryazan region & RO10 & RO3 & $\begin{array}{l}\text { Khabarovsk } \\
\text { region }\end{array}$ & RO4 & RO5 \\
\hline Tyumen region & RO9 & RO3 & Kurgan region & RO7 & RO5 \\
\hline Voronezh region & RO5 & RO4 & Vologda Region & RO8 & RO5 \\
\hline $\begin{array}{l}\text { Chelyabinsk } \\
\text { region }\end{array}$ & RO9 & RO3 & $\begin{array}{l}\text { Arkhangelsk } \\
\text { region }\end{array}$ & RO7 & RO5 \\
\hline Udmurt region & RO9 & RO3 & $\begin{array}{l}\text { Republic of } \\
\text { Buryatia }\end{array}$ & RO7 & RO5 \\
\hline Saratov region & RO9 & RO3 & Kaluga region & FJO1 & FJO1 \\
\hline Tomsk region & RO10 & RO4 & St. Petersburg & FJO2 & FJO2 \\
\hline Pskov region & RO5 & RO4 & Moscow & FJO3 & FJO2 \\
\hline Ulyanovsk region & RO7 & RO4 & Moscow region & FJO4 & FJO3 \\
\hline Kaluga region & RO10 & RO4 & $\begin{array}{l}\text { Kaliningrad } \\
\text { region }\end{array}$ & FJO5 & FJO3 \\
\hline $\begin{array}{ll}\text { Republic } & \text { Of } \\
\text { Bashkortostan } & \end{array}$ & RO10 & RO4 & $\begin{array}{l}\text { Novosibirsk } \\
\text { region }\end{array}$ & FJO6 & FJO4 \\
\hline Rostov region & RO10 & RO4 & Irkutsk region & FJO1 & FJO4 \\
\hline Yaroslavl region & RO5 & $\mathrm{RO} 4$ & $\begin{array}{l}\text { Nizhny } \\
\text { Novgorod } \\
\text { Region } \\
\end{array}$ & FJO1 & FJO4 \\
\hline Omsk region & RO7 & RO4 & Ryazan region & FJO8 & FJO4 \\
\hline Tula region & RO3 & RO4 & $\begin{array}{l}\text { Republic } \\
\text { Tatarstan }\end{array}$ & FJO1 & FJO4 \\
\hline Mordovia region & RO7 & RO4 & Perm Region & FJO7 & FJO4 \\
\hline Smolensk region & RO5 & RO4 & Kirov region & FJO8 & FJO5 \\
\hline
\end{tabular}

\begin{tabular}{|c|c|c|c|c|c|}
\hline Tambov region & RO5 & RO4 & Smolensk region & FJO6 & FJO5 \\
\hline Mari El region & RO5 & RO4 & $\begin{array}{l}\text { Chelyabinsk } \\
\text { region }\end{array}$ & FJO4 & FJO5 \\
\hline Kursk region & RO7 & RO4 & Leningrad region & FJO7 & FJO5 \\
\hline $\begin{array}{l}\text { Krasnoyarsk } \\
\text { region }\end{array}$ & RO7 & RO4 & Mordovia region & FJO4 & FJO5 \\
\hline Tver region & RO7 & RO5 & Vladimir region & FJO9 & FJO5 \\
\hline Oryol Region & RO5 & RO5 & $\begin{array}{l}\text { Ulyanovsk } \\
\text { region }\end{array}$ & FJO6 & FJO5 \\
\hline Leningrad region & RO5 & RO5 & Saratov region & FJO6 & FJO5 \\
\hline $\begin{array}{l}\text { Kabardino-Balkar } \\
\text { Republic }\end{array}$ & RO7 & RO5 & Pskov region & FJO6 & FJO5 \\
\hline $\begin{array}{l}\text { Krasnoyarsk } \\
\text { region }\end{array}$ & RO7 & RO5 & $\begin{array}{l}\text { Republic Of } \\
\text { Bashkortostan }\end{array}$ & FJO1 & FJO5 \\
\hline Primorsky Krai & RO5 & RO5 & & & \\
\hline
\end{tabular}

\section{CONCLUSIONS}

The conducted analysis allows us to make the following conclusions regarding the $\mathrm{FJO}$ and $\mathrm{RO}$ enterprises of subsection DL based on data in 2010-2013.

1. We found the strong positive correlation between the pairs of indicators, related the number of employees and payroll fund (№3 and №4; №5 and №6; №8 and №9). We also find the positive correlation between the production value and the number of employees and the annual payroll fund.

2. We determined statistically significant differences between FJO enterprises and the RO enterprises:

- labor intensity and payroll-output ratio (F2) of FJO enterprises is significantly lower than the RO enterprises;

- number of employees and annual payroll fund (F5) of FJO enterprises is lower than the RO enterprises;

- average salary (F3) of FJO enterprises is higher than the Russian (domestic) ones.

3. Using cluster analysis we confirmed that FJO enterprises are characterized by a smaller size and lower employment compared with RO enterprises. We found only two regions with the high growth rates of employment and payroll, but with low current levels of employment and payroll. The regions, which are major manufacturing centers, do not demonstrate high growth rates of employment and payroll.

It is planned to continue the study of distinctions between foreign, joint and domestic enterprises in Russian electronic industry. We are going to analyze the differences of their investment activity and value added.

\section{REFERENCES}

[1] Unified Interdepartmental Statistical Information System (UniSIS), Russia. WEB: http://www.fedstat.ru/indicators/start.do

[2] "Electronic Statistics Textbook," StatSoft, Tulsa, OK. WEB: http://www.statsoft.com/textbook/

[3] T. Hill, P. Lewicki, "Statistics: Methods and Applications," StatSoft, Tulsa, OK, 2007

[4] R. Almeida, "The labor market effects of foreign owned firms," Journal of International Economics, vol. 72, no. 1, pp. 75-96, May 2007. doi:10.1016/j.jinteco.2006.10.001 
[5] Z. Chen, Y. Ge, and H. Lai, "Foreign Direct Investment and Wage Inequality: Evidence from China," World Development, vol. 39, no. 8, pp. 1322-1332, Aug. 2011. doi:10.1016/j.worlddev.2010.12.006

[6] S. Girma, Y. Gong, and H. Görg, "What Determines Innovation Activity in Chinese State-owned Enterprises? The Role of Foreign Direct Investment," World Development, vol. 37, no. 4, pp. 866-873, Apr. 2009. doi:10.1016/j.worlddev.2008.07.017

[7] S. Girma, D. Greenaway, and K. Wakelin, "Who Benefits from Foreign Direct Investment in the UK?," Scottish Journal of Political Economy, vol. 48, no. 2, pp. 119-133, May 2001. doi:10.1111/1467-9485.00189

[8] J. E. Haskel, S. C. Pereira, and M. J. Slaughter, "Does Inward Foreign Direct Investment Boost the Productivity of Domestic Firms?," Review of Economics and Statistics, vol. 89, no. 3, pp. 482-496, Aug. 2007. doi:10.1162/rest.89.3.482

[9] Y. Murakami, "Technology spillover from foreign-owned firms in Japanese manufacturing industry," Journal of Asian Economics, vol. 18, no. 2, pp. 284-293, Apr. 2007. doi:10.1016/j.asieco.2007.02.002

[10] V. Spitsin, A. Mikhalchuk, L. Spitsina, E. Akerman, T. Nataliya, A. Semes, and D. Novoseltseva, "Comparative Analysis of Salary, Labor Intensity and Payroll-Output Ratio of Foreign and Domestic Firms: Case Russian Vehicle Industry," Proceedings of the 2015 International Conference on Education Reform and Modern Management, 2015. doi:10.2991/ermm-15.2015.97 